\title{
A Faithful Interpreter? Li Zibiao and the 1793 Macartney Embassy to China
}

\author{
Henrietta Harrison \\ University of Oxford
}

\begin{abstract}
This paper is about the interpreter for the first British embassy to China. Li Zibiao was a Chinese Catholic priest who Lord Macartney recruited in Europe and brought with him to China. This account of his participation in the embassy aims to help us understand the role of the interpreter in intercultural negotiations in the late eighteenth century. Interpreting is something we tend to think of as invisible, but in these negotiations, where only a single interpreter was present, the interpreter had significant power. In effect, he acted as a mediator, shuttling between the two parties to enable each to accept the positions of the other so that the negotiations could come to a more or less successful conclusion. This position of power meant that the interpreter's own institutional and personal interests could also be important to the negotiations. Thus loyalty was crucial to how interpreting worked. Ly's achievement during the negotiations was to create a situation where both Lord Macartney and the Qing officials were willing to accept him as a mediator and where he survived to tell the tale.
\end{abstract}

At the end of Lord Macartney's embassy to the court of the Qianlong emperor the British sailed home from Macao. Li Zibiao, the Chinese priest who had acted as interpreter, stayed on in Macao and wrote an account of the embassy to his superiors in Rome in order to justify his participation. ${ }^{1}$ He began by explaining that, "Things turned out unexpectedly, so that instead of secret interpreting (for that was what I had been assigned and intended to do) I became an interpreter of words, since after we disembarked from the ships into the Chinese skiffs, no one who was familiar with Chinese dared to join the embassy."2 At the end the embassy he said that he had turned down invitations from Qing officials, including the governor of Guangdong province, to return with the next British embassy, and also offers from the British to work in London. He explained that he did so because he knew that his duty was to wait to learn how he could satisfy the vow to be a missionary he had made when he had entered the College of the Holy Family in Naples. "It was for this same religious reason that I became involved in matters of this world, and wasted my time and effort, but never now it is past have I regretted undertaking something that not even the most stupid person would have done if they had understood the danger.”3

Since the rise of simultaneous conference interpreting in the mid-twentieth century with its microphones and glass booths, there has been a widely held image of interpreting as a perfectly transparent process in which the interpreter becomes invisible as an extension of the speaker whose words he or she is translating. ${ }^{4}$ 
Conference interpreting is of course only a small part of the work of interpreters today, but the effect of the image has been to concentrate attention on the process of translation and away from the person of the interpreter. This has shaped Englishlanguage scholarship on the history of interpreting even when the author is writing against it, as is the case for one of the best recent works, Kumiko Torikai's Voices of the Invisible Presence. ${ }^{5}$ Chinese language historians of interpreting have a greater tendency to institutional history, since China has a long tradition of government institutions for training and providing diplomatic interpreters, but their work too is shaped by commitment to the modern norm. ${ }^{6}$

In the late eighteenth-century the ideal of the diplomatic interpreter as a transparent translator of words did exist, but in practice interpreters also acted as informants, negotiators, and mediators. ${ }^{7}$ This role carried significant, but temporary, power. Because of its importance and difficulty the interpreter needed to be someone of considerable ability and was therefore likely to have wider interests and ties that might affect the negotiations. It mattered greatly to the principal parties to the negotiations who the interpreter was and what his loyalties were. For the same reason the position of interpreter was a dangerous role to hold. Relations of trust were vital to all concerned: the principals risked failure in their negotiations while the interpreter, as the weaker party, was even more vulnerable. Trust could be created by the principals binding the interpreter into a shared world of male sociability, but also through institutional incentives and through threats. Invisibility comes into play because it was a possible solution to the interpreter's vulnerability: by creating the illusion that the principals were speaking directly to eachother, the interpreter could, if he wished, conceal his own role in the negotiations.

Li's accounts of his experience in this and other letters, along with of the abundant British and Chinese documents about the embassy, enable us to examine the role of the interpreter in intercultural diplomatic negotiations in the late eighteenth century. His story shows us that while loyalty was a key virtue in contemporary understandings of interpreting, interpreters in this period were not simply representatives of nation states. Rather multiple personal loyalties cut across national stories as interpreters like other diplomatic agents pursued personal, institutional and ethnic interests. Li's loyalty to the Catholic church caused him to intervene surreptitiously in the negotiations at considerable personal risk and when that failed to adopt a position of invisibility, but his identity as a member of a religious congregation associated with the papacy rather than the Portuguese and as Han Chinese rather than Manchu were also important in how he was treated. ${ }^{8}$

\section{British and Chinese expectations of interpreters}

British expectations of interpreting for the embassy are well illustrated by the events that took place during the negotiations with Tipu Sultan that ended the Second Anglo-Mysore war in 1783. George Macartney, as governor of Madras, was responsible for these negotiations and he sent his aide George Leonard Staunton to carry them out, so there is a direct link with the embassy to China when Macartney 
and Staunton were also the principals in the negotiations on the British side. On both occasions there was considerable tension between the interests of the British government and those of the East India Company, and Macartney and Staunton were close identified with the government. During Staunton's journey across south India to meet with Tipu Sultan interpreting became a major issue in his relations with Anthony Sadleir, who represented the interests of the East India Company's merchants in Madras. Staunton and Sadleir's letters on this occasion provide a good sense of the issues and expectations in interpreting at this time. In India at this time written translation of diplomatic correspondence, which was usually in Persian, was undertaken by British men who had learned the language: in this case David Haliburton, who held the office of Persian Translator in Madras, and other men with similar posts in the army and East India Company. However, Haliburton was not able to act as a spoken interpreter and had not accompanied the embassy. ${ }^{9}$ Instead Sadleir brought with him his dubash one Choleapah Moodely. ${ }^{10}$ Although the title dubash means interpreter, such men could also be powerful merchants in their own right. ${ }^{11}$ Choleapah was clearly a man of considerable ability and soon became the chief channel of communication with the Mysore agents. ${ }^{12}$ In this he quite outshone Staunton's man, Vincata Rangih, who was the East India Company's interpreter for the port of Cuddalore. ${ }^{13}$

The dispute blew up when Tipu Sultan's agents began direct negotiations with the interpreters. Staunton and Sadleir were not present at the discussions, but an English secretary attended and wrote up a report. Sadleir rejected this saying that his man Choleapah had given him a different version of what had been said. The secretary insisted that he had written down everything important and only ommitted repetitions and "compliments agreeable to oriental custom and policy." ${ }^{14}$ The issue, of course, was what should be considered mere compliment and what was crucial to the negotiations. Sadleir and Staunton asked Tipu Sultan's representative for his version of what had been agreed, only to find that his notes made no reference at all to several of their complaints. Staunton was convinced that Choleapah was planning to create a situation where Tipu Sultan would bribe him (and possibly also Sadleir), to act against the interests of the British state. Thus he was horrified when Tipu Sultan himself acknowledged Choleapah's importance by asking after him personally as soon as the British arrived at his camp. ${ }^{15}$

Staunton condemned Madras dubashes as a group because their occupation as middlemen meant that they were "bred in habits of cunning and adulation and are not exempt from the imputation of a disposition to venality." 16 His primary concern, however, was that Choleapah would be loyal to Sadleir and the interests of the East India Company merchants, not to him. His response was to propose a quite different role for the interpreters. He demanded that he and Sadleir should be present at all meetings. The proper behaviour of interpreters was what he claimed had happened at the beginning of the embassy, when the interpreters were concerned "simply in Translating every separate sentence or words as it was spoken on either side, but the Subjects, the argument, the method, the whole scope of the discussion depended on 
the Principals.” 17 The point soon became moot, because Sadleir and Staunton refused to speak to each other and began to communicate by memo, making any spoken negotiation impossible. Once the indeterminacy of speech was eliminated, something much closer to Staunton's proposal for translation was possible and they could explain disagreements as the result of linguistic errors or nuance, writing to Tipu's representatives that "we are aware, with what facility expressions may be mistaken in passing from one language to another." 18 However, it is clear that this idea of words passing from one language to another was far from how the interpreters worked at the beginning of the embassy.

In China, the longstanding ideal was that all diplomatic interpreting should be controlled by the state. Interpreters handling embassies were supposed to be officials in the College of Translators and Interpreters (Huitong siyi guan), an institution that had its roots in the early Ming dynasty. ${ }^{19}$ The college provided training in a wide range of languages ranging from Sanskrit and Persian to Uyghur and Thai. At different times in the eighteenth century both Latin and Russian were taught: in 1729 a class in Latin was added to the College of Translators and Interpreters and taught by Jesuit missionaries. ${ }^{20}$ Russian had its own institution, the Russian Language College (Eluosi wenguan), whose teachers included Russians captured on the frontiers and others sent to China on diplomatic missions. ${ }^{21}$ Missions from Korea, Japan and the Liuqiu Islands used written Chinese and brought interpreters with them who were also understood as officials. ${ }^{22}$ On China's frontiers interpreters known as tongshi were low level state functionaries. In areas like Taiwan where Qing control was expanding they were often the first level of local government. ${ }^{23}$ In Guangzhou (Canton), where they were known to the English as linguists, they received a tax on all foreign trade transactions and were responsible for the official paperwork needed by the foreign merchants. $^{24}$

However, in actual practice these Chinese institutions had difficulty producing people with the linguistic skills to interpret for a diplomatic mission. The College of Translators and Interpreters was under constant criticism: its classes came and went, while its students were said to be unwilling to study for a lowly rank with limited prospects. On the southern coast, although a significant number of Chinese in Macao spoke fluent Portuguese, the official linguists in Canton had merely enough English to do their job. ${ }^{25}$ Thus the Qing had to employ individuals with unusual life stories as interpreters. For everyday puproses they could use defectors and prisoners captured on the frontier for Russian, and get documents in European languages translated in Macao. ${ }^{26}$ For diplomatic negotiations with Europeans the court usually turned to the Jesuits in Beijing: for the negotiations that led to the Treaty of Nerchinsk in 1689 the Kangxi emperor employed Tomé Pereira. Catherine Jami has argued that he chose Pereira because he regarded him as a loyal servant, and it was for this reason that the negotiations were conducted in Latin rather than Manchu, Russian or Mongolian. ${ }^{27}$ The choice led to disputes with the Russians as Pereira also pursued a Jesuit agenda in the negotiations. For the Chinese, as for the British, the potential power of 
interpreters during diplomatic negotiations was a threat, and issues of trust were crucial to their appointment.

\section{Building a Relationship with the Interpreter}

Trust was not seen by either the British or the Chinese as a simple result of national origin but rather something that could be constructed: Staunton distrusted Sadleir quite as much as he distrusted Choleapah, and on occasion the Kangxi emperor chose to use European Jesuits rather than Mongol-speakers from his own court as interpreters. ${ }^{28}$ This was because internal rivalries were often as important for the negotiations as those with foreign states: when Macartney was offered the position as ambassador to China he was determined not to use anyone with a primary loyalty to the East India Company as an interpreter. His relations with the Company while he was in Madras had been fraught, but he was also making a realistic assessment that those profiting from the existing trade arrangements in Guangzhou would have an interest in continuing them. He wrote to Henry Dundas, Home Secretary and close ally of Prime Minister William Pitt, that he intended to take some gifts to conciliate the Jesuits in Beijing who might act as interpreters, but

Prudence however requires not entirely to trust, if possible, to Interpreters, now either at Pekin or Canton. They might have local views and connections, or feel themselves under too much awe, to be able faithfully and completely to render the sense of the most decent representations. It were therefore desirable to find in Europe a good Chinese Interpreter, who might communicate a variety of hints and instructions, and even some notions of the language, whilst onboard Ship, and above all might contract in the necessary intimacy of a long voyage, an Attachment which would ensure fidelity and zeal in the Service. His sentiments at least and real character could not fail of being discovered, and of shewing what degree of dependence should be placed upon him; in all events, he would serve as a check upon the resident Missionaries. $^{29}$

To find such a person Macartney decided to use his secretary's close links with the Catholic church. George Leonard Staunton was Irish from a mixed CatholicProtestant family and had been educated in a Jesuit college in France. ${ }^{30}$ He began his search through contacts in France and from there found out about the college in Naples where Chinese men were trained for the priesthood. Staunton selected two of the men who had completed their training and came from north China, which he knew had a different dialect from Guangdong: Li Zibiao and Ke Zongxiao. Two more, Yan Guanren and Wang Ying, then joined the embassy in London and sailed as passengers. ${ }^{31}$

Social rank was an important criterion in the selection of pupils for the Naples college: Li Zibiao came from a wealthy Chinese family in Wuwei, a trading town in China’s northwestern Gansu province. His older brother Li Zichang joined the Green 
Standard Army, the main military force recruiting Han Chinese, and went on to be honoured for his bravery in campaigns suppressing rebellions in Sichuan and Taiwan and rose to the rank of general. ${ }^{32}$ In later generations the family would produce some of the town's most famous scholars. ${ }^{33}$ The family had probably converted to Catholicism in the early eighteenth century, when for a time there was a resident Italian missionary. ${ }^{34}$ After that there was no Catholic priest in this part of China for many years and it was this that motivated Li's father to send his younger son, then aged just 11, to Naples in 1773 to study for the priesthood. ${ }^{35}$

The College of the Holy Family (commonly known as the Collegio dei Cinesi) had been founded specifically to train Chinese men for the priesthood, but over time had also developed into a school for the sons of the Naples elite. ${ }^{36}$ This was the environment in which Li Zibiao spent the next 19 years of his life. When he arrived he was still a child, and was also several years younger than the other Chinese students most of whom were in their late teens and twenties. Soon his best friend was Giovanni Borgia, only son of the Duke of Vallemezzana and Cosentini. ${ }^{37}$ These boys received the classic humanistic education that bound together the European elites of this period. Li learned to speak Latin in the classroom and Italian informally. The Chinese students read all the major classical Latin texts beginning with Cicero's speeches, then going on to the great epic poetry of Vergil, the poems of Horace and Ovid, and even Lucretius' entirely unreligious writings on atoms. ${ }^{38}$ Then they were taught the art of public speaking by Felice Cappello, a well known educationalist who published two of the textbooks he composed while at the college. His textbook on rhetoric urges the general importance of training in public speaking for careers in both the church and the law. ${ }^{39}$ These rhetorical skills almost certainly shaped the way in which Li spoke and interpreted for Macartney.

In addition Li continued to speak and study Chinese while he was in Naples. The Chinese students all lived together in a large dormitory and were required to continue to study Chinese texts in preparation for their future mission. Originally there had been a teacher brought from China specifically for this purpose, but by the time $\mathrm{Li}$ arrived the arrangement was for one of the older Chinese students to teach the younger ones. ${ }^{40} \mathrm{Li}$ would have been taught by the son of a military official in Beijing, a young man who had received a good education in China before he left for Naples at the age of $19 .{ }^{41}$ Later generations were taught by Yan Guanren, who was the son a wealthy Fujian merchant, and was one of the other students who returned to China with Macartney. ${ }^{42}$ While the kind of education such a teacher could provide would not have been of the highest order, it would probably have been quite similar to that in many traditional Chinese schools.

Li was an outstanding student and much loved by both his teachers and his classmates. In 1776 Gennaro Fatigati, the superior of the college, reported that "this Chinese boy has done better than all the others in the Latin language." 43 He also commented that Li was devout, modest and well behaved. Clearly the young age at which he arrived in Naples made Li quicker at picking up languages than the older Chinese students. His close friendship with Giovanni Borgia, which was unusual 
among the Chinese students in its intensity, no doubt also helped. Added to this he was very bright: later school reports constantly list his "excellent ability." 44 It is also clear that from his arrival Li was Fatigati's favourite student. Fatigati himself was unusual among the Neapolitan priests living and teaching in the college as a man of deep spirituality: he was hugely admired for having turned down the significant financial rewards of a bishopric in order to remain at the college. Li's later correspondence often echoes Fatigati's spiritual style, something that is very unusual among the Chinese students, and suggest that he too came to speak easily in this way. Fatigati was of an age to be Li's grandfather and his constant affection for the boy no doubt encouraged Li to internalise the values that he represented. It also seems likely to have been one of the reasons for Li's great confidence and security throughout his life. Li's sincere demeanour combined with an easy assumption that others would respond well to him was to be crucial in his time as an interpreter.

When Staunton arrived in Naples, $\mathrm{Li}$ and his classmates were eager to return to China and start work as missionaries, but the college had for some time been unable to afford the costs of the voyage to send them home. Staunton told the College authorities that the only responsibility of the Chinese would be to instruct the embassy in the customs and language of China on the voyage before leaving the embassy at Macao. ${ }^{45}$ This fitted with Macartney's plan of finding an interpreter, winning his loyalty through friendship, and only later telling him what was required. From the start Staunton treated $\mathrm{Li}$ and Ke as gentlemen with "finesse and good manners" and we can follow the progress of Macartney's plan in Li's letters back to the superior Massei and the other Chinese students in Naples as they travelled across Europe. ${ }^{46}$ The party spoke in Latin, a language in which Staunton was fluent because of his seminary education and in which he also spoke to his young son. By the time they reached Brussels it is clear that Li's relationship with Staunton was deepening. They must have discussed politics since Li wrote back to his Chinese classmates about British parliamentary reform giving Irish Catholics their rights. ${ }^{47}$ Staunton was an ardent supporter of the French revolution, while Li's politics were much more conservative: he was pleased to see French refugees wearing the king's cockade because he hoped for the defeat of the revolution and restoration of the French monarchy. The two men had their differences about religion too, but it is clear that by this stage they were discussing the matter at a much deeper level than they had at the start, and that Staunton had revealed the extent of his links to the Catholic church to $\mathrm{Li}$ in a way that he very seldom did elsewhere. He attended devoutly when Li or Ke said their daily mass and paid for someone to take them secretly to Catholic Sunday services in the Lutheran areas they had passed through. Li probably even urged Staunton to convert from Anglicanism to Catholicism because he reported that Staunton was "obstinate in his religion and does not want to change it."48 Staunton did however, tell Li that his mother was Catholic, something that the lengthy biography that his son later published about him omits. ${ }^{49}$ This was a sign of real trust, because Staunton was the subject of public attacks for his apparent links with the Catholic church which were a significant risk for his career. 
In London Li and Ke stayed in Staunton's house and met Macartney, with whom they spoke a mix of Italian and Latin. ${ }^{50}$ The eight-month boat journey to China strengthened Li's relationship with the two men. He and Ke as the nominated interpreters sailed on HMS Lion with Staunton and Macartney, while Yan and Wang travelled with the lower ranking embassy members on the East India Company ship the Hindostan. An eighteenth-century warship was not a large space and there was a lot of opportunity for conversation, moments of shared laughter, and also of great danger. As the captain followed the great current that flows east around Antartica, gales carried away one of the ship's masts, filled the lower cabins with water, and eventually left the ship with no option but to bring in all the sails and simply run through the huge swell before the wind. By the time the captain turned north towards the East Indies the ship was leaking eight inches of water an hour. ${ }^{51}$ Then, after the ship left Batavia (now Jakarta) it was becalmed when the monsoon winds that would take them to China failed to arrive. In the intense heat and crowded living conditions dysentry and fevers spread among the crew. Sixteen of the sailors died between Batavia and Macao and Li himself became desperately ill with scurvy. ${ }^{52}$

When HMS Lion reached the waters off Macao, the three other Chinese went ashore as had originally been planned, but Li made the decision to continue with the embassy to Beijing against the wishes of his superiors. Macartney saw this as evidence of the success of his efforts to build a relationship with Li over the course of the journey. He reported to Dundas in London that he had

a sufficient Interpreter, thro' the medium of the Italian language, in one of the Neapolitan Chinese, a sensible Man, of a firm mind and good disposition, who becoming attached to me, overcame every apprehension of the danger arising from being found without permission, in the Service of a Foreigner, and agreed to accompany me throughout, continuing his European dress to avoid, if possible, discovery - while his companion could not resist the fears he entertained on the same ground, and left us at Macao. ${ }^{53}$

Giambattista Marchini, the procurator of the Catholic missions in Macao, on the other hand, was horrified when Staunton brought him a letter from Li explaining his decision to go to Beijing as a person "in whom the ambassador placed great trust." 54 He was worried about what would happen if the embassy went badly: Li would be discovered as a Chinese and a priest and this would have grave consequences not only for him but for the whole Catholic mission in China. ${ }^{55}$

Li's response to the risks was to continue wearing European dress, adopt an English name (Mr Plum, an English translation of his Chinese surname, recorded by the Chinese as Loumen), and rely on the striking capacity his unusual childhood had given him to conform to another culture. ${ }^{56}$ Staunton commented that because Li came from China's far northwest he did not look quite like the other Chinese, and Yan Guanren wrote back encouragingly to Naples that Li was not afraid of discovery because he was an astonishingly good actor. ${ }^{57}$ None of these things, however, was 
much of a disguise and Marchini's fears were not unreasonable. As everyone knew, thirty years earlier the East India Company merchants in Guangzhou had attempted to break the monopoly of the Chinese merchants by sending James Flint, their interpreter, with a petition to Ningbo to ask for permission to open trade there. When this failed Flint sailed on north to Tianjin where he was arrested and imprisoned for two years. His Chinese assistant Liu Yabian was executed. ${ }^{58}$ One of the other possible interpreters for the Macartney embassy, a Chinese man who had lived in the Philippines and thus spoke fluent Spanish and Portuguese, withdrew once he realised the risks. He was the son of a merchant who also taught Chinese to some of the English merchants in Macao. They reported that he set off "with zeal and alacrity" and was ambitious to meet Macartney and go to Beijing. ${ }^{59}$ However by the time the ships reached north China he had been so scared by the questioning and threats he had received while negotiating for pilots on the way, that he refused to continue with the embassy. ${ }^{60}$

\section{Qing Officials' Trust in the Interpreter}

Macartney chose Li as interpreter and persuaded him to go to Beijing as a result of the relationship he had built between them. However, this would not have been enough for successful interpreting without similar confidence in Li from the Qing officials in charge of the embassy. Macartney introduced Li as his $3^{\text {rd }}$ Secretary, a relatively low ranking role, but from the start the Qing officials treated the interpreter as the third ranking member of the embassy after Macartney himself and Staunton. ${ }^{61}$ This was conventional Chinese treatment of visiting embassies and reflected the perception of interpreters as state functionaries. It also had the effect of placing the interpreter in direct contact with high officials, where confidence and personal relationships might develop. Liang Kentang, the governor of Zhili who was a stickler for correct protocol, gave Li's assumed name of Plum (Loumen), in his report on the embassy's arrival and recorded the speeches as being made by Plum on behalf of the ambassador. ${ }^{62}$ Li's seniority was confirmed in his treatment as the embassy travelled from the coast to Beijing. On the river journey inland, the procession began with Zhengrui, the senior official in charge of the embassy, and his suite in five barges, then Macartney, Staunton and Li each with a barge of their own, and then the rest of the Macartney's retinue in groups. ${ }^{63}$ When they disembarked in Tongzhou near Beijing, Macartney, Staunton and Li were carried in sedan chairs, while the rest of the embassy got carts - to their considerable annoyance. ${ }^{64}$

When the embassy arrived in the capital there was a dispute over where they should be housed which gives a good sense of Li's role. The house they had been allocated was in Haidian, a village a little to the north of the city, near the emperor's garden residence, the Yuanmingyuan. This made sense from the point of view of Qing officials, since the Yuanmingyuan was the site of the European-style palaces and was where the British gifts were to be displayed. ${ }^{65}$ Macartney objected to the house on sight. From his point of view it was outside the city, not big enough, dilapidated, and quite unfurnished. ${ }^{66}$ So when the embassy arrived Macartney’s 
retinue, exhausted from their journey in the uncomfortable carts, found themselves standing in a corridor with nowhere to go. Eventually, "unable from fatigue to stand it longer, they all marched in a body in quest of his Lordship and Mr Plumb, whom they found disputing with the mandarines about the appartments not being sufficiently spacious."67 It appears from this that Li was with Macartney and quite likely translating the words Macartney spoke rather than negotiating himself.

These initial complaints failed and the embassy settled into the house, but the dispute continued and became involved with the issue of who should act as the embassy's interpreter to the emperor. Both Macartney and, as it happened, the Qianlong emperor had assumed up to this point that the Beijing Jesuits would take on the bulk of the interpreting for the embassy. Macartney had originally stated to Dundas that Li's role would be as his personal interpreter who could keep a check on what the Jesuits were saying and this was evidently also what he told Li. The emperor had decided to appoint the Portuguese Jesuit José Bernardo de Almeida as interpreter giving him an appropriate official rank for the office. ${ }^{68}$ Macartney, however, thought that Almeida would support the Portuguese interest in maintaining trade through Macao against the British desire to break the monopoly by trading outside Guangdong. Instead he wanted one of the French Jesuits, since in the aftermath of the French revolution's anti-clericalism he thought that they would have little national interest in the outcome. ${ }^{69}$ The result was a most uncomfortable formal meeting between Macartney and the Beijing Jesuits in the presence of Zhengrui. ${ }^{70}$ Macartney ordered the members of his suite to pretend that they did not speak Latin, which they found both demeaning and implausible, especially as Staunton was whispering to $\mathrm{Li}$ in Latin. ${ }^{71}$ During the meeting Macartney tried again to get the embassy's residence moved into the city, but Almeida did not support him. Instead, Almeida's words to Zhengrui implied that Macartney was not genuinely keen to go on to meet the emperor, who was spending the summer at his palace in Chengde up in the hills beyond the Great Wall. ${ }^{72} \mathrm{Li}$ thought that this was the result of imprudent interpreting by Almeida which had resulted in Macartney's request being misunderstood. ${ }^{73}$ In any case Zhengrui refused the request.

Li's letter to Naples explains what happened next:

A sharp dispute arose between the Officials and the Ambassador. When the negotiations were forcefully disturbed, the two Senior Officials who accompanied us, called His Excellency Qiao and His Excellency Wang, came hurrying to find me demanding in a great state of excitement that I would set out openly the Ambassador's opinions and reasons, which I knew full well, so that I could explain the original cause of his excited behaviour, which would certainly remove the reason for the present dispute. I did not do so, saying that I was really tired from the previous days and quite exhausted by the work I had done, which was not my job, and that I was not an interpreter if they could find another, and that if I had done it from time to time it was not because it was my job but out of necessity. But they would not accept my 
arguments at all, but at length made great progress, so that I gave in to them not because they were right, but because I was overcome by their demands. I came from where I was to the President of the Board, and explained the Ambassador's thinking to him and why he so much wanted to stay in the city of Beijing, and that certainly as soon as his things were all safely arranged in whatever place was decided on, he would be able to leave quickly for the Emperor, who was then staying in Rehe, and that it was certainly not the case that there was anything wrong with the house in Haidian or that it was unworthy of such an important Ambassador. ${ }^{74}$

Jinjian, the President of the Board of Works, agreed with this reasoning. An alternative residence in the city was identified and Li made several trips into the city to approve it and make the arrangements. ${ }^{75}$ One striking feature of this account is that the job of the interpreter, as Li saw it, was not to transmit Macartney's speech into Chinese, but rather to explain why Macartney thought as he did and to use persuasion to reach a solution that was acceptable to all. In pursuit of this goal he clearly had no qualms about stating the precise opposite to Macartney's opinions if need be: Macartney did indeed think that the house unworthy of him as ambassador, but this was scarcely a tactful thing to say to the officials who had provided it. ${ }^{76}$

A few days later a letter arrived from Heshen, the senior minister on the Grand Council, to Wang Wenxiong and Qiao Renjie who were in charge of the embassy's day to day affairs, telling them to appoint Li interpreter to the embassy for the imperial audience in Chengde. They told him that this was "for the sake of minimising any controversy that might arise."77 Li's understanding of events was that this was the result of his relationship with Qiao and Wang. He wrote that as a result of the disputes that had taken place "the senior grand councillor He[shen] zhongtang relying on the account given by the officials made me interpreter to the Emperor and rejected all the others." ${ }^{78}$ It was in fact perfectly conventional for the third ranking member of an embassy to be an interpreter and to attend the imperial audience in that position. Nevertheless there had clearly been an earlier decision to use Almeida, so a decision was made by the Qing officials to use $\mathrm{Li}$ and it is interesting to consider the reasons for this. It seems that they, like Macartney, had decided that they were willing to trust him.

One possible explanation for Qing officials' trust in $\mathrm{Li}$ is that, although he was committed to the success of the embassy as an event, he was by no means always in favour of either Macartney's negotiating goals or his behaviour. Bruce Anderson, in one of the most interesting studies of the role of the interpreter, has suggested that an interpreter who has an equal interest in the ends of both parties is likely to manipulate the content of negotiations towards moderation and to aim for what he sees as a just outcome where both sides believe that they have maximised their gains. ${ }^{79}$ This certainly seems to describe Li's attitudes and behaviour. Although he had spent many years in Europe, his birthplace and family identity was Chinese and his education in Naples had placed a great emphasis on this Chinese identity. And although he had 
arrived with Macartney, he had no particular reason other than friendship to identify with the British. Likewise, the expansion of British trade was not a goal he shared, except in so far as it might benefit the interests of Chinese Catholics and the papal mission. His attitude towards the embassy's goals was balanced, but from the start somewhat distant.

As the embassy progressed Li became increasingly critical of Macartney's behaviour. Although he smoothed over the disputes about where the embassy should stay, his own opinion was that in complaining about the house Macartney was behaving "as if drunk with too much honour." ${ }^{80}$ As it happened this was also the Qianlong emperor's view: when Macartney refused to perform the kowtow he wrote, "When they were coming to the capital, the local officials in the places they passed through all entertained them and provided for them, and could not avoid treating them too well, with the result that the envoy and his party became recklessly arrogant." 81 It may be that this idea was conveyed to $\mathrm{Li}$, since as the interpreter he was the person who actually received the rebuke that followed, and that was why he later incorporated it in his letter. ${ }^{82}$ Or he may simply have come to the same conclusion on his own account. In either case it is clear that his personal opinions were quite strong and were not always favourable to Macartney.

Later on in the embassy the courier Aeneas Anderson, remarked that at one point meals arrived cold for several days and "Mr Plumb, the vehicle of all complaints, and who, in general, contrived to procure redress, was employed." ${ }^{83}$ This (no doubt rather wearing) role inevitably meant that Li was constantly working with Qiao Renjie and Wang Wenxiong. On the road north to the Emperor's palace in Chengde a Manchu servant was beaten for stealing some of the embassy's utensils. When he was released he insisted that a Chinese couldn't beat a Manchu outside the Great Wall, upon which Qiao and Wang had him beaten again, and Wang remarked to Li that a Manchu would always be Manchu. ${ }^{84}$ This anecdote, recorded by Macartney, suggests that there was a considerable degree of trust between the two. On the one hand, this was a period when any kind of anti-Manchu slur could lead to terrible repercussions, so Wang put himself at risk by his remark. On the other hand, he also made it clear that he knew perfectly well that Li too was Han Chinese, and not English as he had claimed to be. As interpreter Li represented the English, but he was also at times on the side of the Chinese. The Qing officials who worked with him could hardly fail to be aware of this.

Li's position between the two parties continued during the embassy's time in Chengde and was one of the ways in which the disagreements between the two sides could be smoothed over to achieve a result which was, at least at that moment, acceptable to both. At the audience with the emperor Li was treated as the third ranking member of the embassy. He dined with Macartney and Staunton at the side of the Qianlong emperor's throne, while the rest of Macartney's retinue remained outside. Of course he needed to be there to interpret, but the emperor also presented Li with a gift with his own hands, as he did to Macartney and Staunton. ${ }^{85}$ Heshen also invited Li to his house and offered him a gift. ${ }^{86}$ A few days later Heshen gave 
Macartney a tour of the vast imperial gardens. They were accompanied by Fukang'an, a Manchu who was both the Governor General of Guangdong and Guangxi (the most senior official in charge of the British trade) and also simultaneously the general leading campaigns against the expansionist Gurkha state on the Tibetan borders, along with the Mongol Songyun who had just arrived from negotiating with the Russians on China's northern border. Earlier Fukang' an appears to have attempted to get Macartney to kneel when he addressed the emperor, as was normal practice, by pulling his sleeve and touching his head, but Macartney misread this as indicating that he should remove his hat. ${ }^{87}$ However, during the tour of the garden Fukang'an made sure that $\mathrm{Li}$, who was speaking for the British, did so only on his knees. ${ }^{88}$ Meanwhile Li constantly soothed and encouraged Macartney, telling him the negotiations were going well, but was also annoyed that Macartney (who was suffering from painful gout) was not friendly enough to the Qing officials. ${ }^{89}$

Li remained constantly aware of the risks of his position, especially when Macartney "acted with less and less courtesy so that nearly all the officials came to hate him” and all the embassy's demands were refused. ${ }^{90}$ As he wrote,

In this truly difficult situation I should have been afraid of the danger hanging over me, since I and I alone was speaking with everyone and handling everything, even what was offensive to the senior Ministers, but God miraculously protected me in the many and varied storms around this mission. I don't know what caused them to think so, but all the Officials even Heshen, looked on me as though all the negotiations had been appropriate, even though they knew that I was Chinese. ${ }^{91}$

The last sentence is his only possible reference to a claim made by the Macao procurator Marchini that Fukang' an had threatened his family. Marchini was worried that $\mathrm{Li}$ "was in great peril" and reported that someone in Beijing (presumably one of the missionaries) had informed him that Fukang' an had said to Li, "You're one of us. You'll pay for it. Your relatives depend on me and they'll pay for you."92 This was gossip and the words are far from reliable, but it was perfectly correct about Li's situation: his brother Li Zichang was Fukang'an’s protégé and military subordinate: he had probably joined the army in the early 1780s during the Muslim rebellion in Gansu where Fukang'an was second in command. Certainly he first came to prominence under Fukang'an in the Taiwan rebellion, and had then gone on to a senior military position in Guangdong under him. ${ }^{93}$ Moreover, Li Zichang had been eager to meet his younger brother arriving back from Italy after so many years, and had now hurried north to Beijing, where he arrived shortly after the audience with the emperor. ${ }^{94}$ This suggests that for Qing officials the creation of relationships to ensure trust could easily have been backed up by the use of threats, though it might also have been one of the reasons that they were willing to trust Li Zibiao. In any case, even if no open threat was ever made, Li must have been aware of the huge risk to his brother and maybe also his wider family if he got into trouble. 


\section{The Power of the Interpreter}

If we see the interpreter as someone with both potential power and interests of his own, then it was always likely that he would pursue those interests during the negotiations. At one level $\mathrm{Li}$ had an interest in an outcome of the embassy that would ensure his own personal safety and might also fulfill his ideas of what would be a just outcome for both parties. However, his strongest loyalty was to the church and especially to Chinese Catholics: he himself stated that he took the risks of interpreting for the sake of his religion. Unsurprisingly he also pursued those interests during the negotiations. While he was in Beijing he sent a request to the emperor to allow Chinese Christians to practice their faith. ${ }^{95}$ This request came ostensibly from Macartney, but it appears to have been separate to the main set of British demands, which were handed to the emperor in a gold box at the audience in Chengde, and $\mathrm{Li}$ did not inform Macartney. There is thus no record, other than Li's own claim, for the text of this request. However, the emperor's reply, which dealt with each of the British demands separately, included a section refusing the request. ${ }^{96}$ This created a nerve-wracking situation for Li when the actual discussions of the British demands and the emperor's responses took place during the embassy's journey back to Guangdong.

The senior Qing official who accompanied the embassy south was Songyun, whom Macartney had already met and liked in Chengde. Songyun was an expert on the northwest and China's frontier with Russia. He had been sent to persuade Macartney to accept the emperor's decisions so that the British did not cause any kind of trouble on the southeast coast. ${ }^{97}$ Songyun moved slowly and cautiously, and it was only after three weeks of travelling together by barge down the grand canal and discussing Russia and other subjects of general interest, that he addressed Macartney on the subject of the emperor's formal response to the British requests. ${ }^{98}$ His explanation included both a rebuke to the ambassador for adding to the British king's requests, and an explanation of the emperor's refusal of the British demand for freedom for Chinese Christians. Macartney, who knew nothing about this, was startled and quite put out. As he pointed out in his letter to Dundas, he had not even brought a chaplain with him. ${ }^{99}$ His version of the conversation with Songyun that followed this revelation was that he explained that the British thought all religions equally pleasing to God and that, unlike the Portuguese, they were not interested in conversions. ${ }^{100}$ Songyun's report to the emperor gave a somewhat different version of Macartney's response. According to him, rather than instantly denying the request, Macartney returned the following day and clarified it, explaining that,

We have understood everything and are truly grateful. The only thing in the emperor's letter that we still do not understand is the item that refuses the practice of religion. Our original request was to beg the Emperor to bestow on the Europeans living in China permission to continue to practice their religion, 
we certainly did not mean that we wanted English people to practice their religion in the capital. ${ }^{101}$

It is possible that either Macartney or Songyun was lying about what was said, but it seems more likely that Li was taking advantage of his position as interpreter, when neither side understood what the other was saying, to shape the negotiations to his own ends. Having had the request for Chinese Christians to practice their religion refused, Li reformulated it as a request for the European Jesuits to continue to preach. In any case Songyun replied to this at some length, explaining that China had its own teaching passed down through the generations and it would be quite wrong for the emperor to allow the common people to be disturbed by different teachings. He then assured the English (or possibly the nervous interpreter) soothingly, that "What you have done today is quite right, and if it is as you explain then you have no need to be afraid." 102 Macartney insisted on writing a note of clarification to Heshen, in which he laid out his own universalistic religious beliefs, explaining that the British merchants in China have no chaplains and clergy.

"They come solely for the purpose of Trade, satisfied that the great Creator of the World, equally accepts the Homage of his Creatures in the different modes of Worship which he has permitted to be adopted, and excludes none from his favor whose merits and good intentions are pure and sincere.”103

Macartney put the mistake down to an error in translation and wanted to investigate it, which focussed attention on Li and the Jesuits who had provided a written translation. It was a moment of high risk for $\mathrm{Li}$, but as he recounted later,

"His Excellency Song is a mild man with an indulgent nature, so he did not accuse the European interpreter of the letter of treachery, but excused it on the grounds of lack of skill in a foreign language, adding at the same time that this interpretation was absolutely not correct." 104

Up until this point, although Macartney often wrote as if he were speaking directly to the Qing officials, the Chinese documents very often present the British speeches as being made by the interpreter. This was almost always the case when the embassy first arrived, but continued in Songyun's reports to the emperor on the journey south which frequently mentioned the interpreter Plum. ${ }^{105}$ After this moment of high tension over the request for Christian tolerance, the interpreter disappears from the Chinese record of the embassy. Songyun began to record speeches as being made by "the envoy". ${ }^{106}$ Two weeks later, for the first time he used Macartney's name (though the Chinese courtesies that follow sound much more like Li than Macartney). ${ }^{107}$ It appears that $\mathrm{Li}$, having prudently accepted that his efforts to assist the church had failed, was intentionally effacing himself. Invisibility had become a way out of the risks he faced when he attempted to use the power that his position as 
interpreter gave him. The fact that the British had an ideal of intepreting as a transparent process of the transmission of words between languages was part of what made this possible, even though that was not the everyday practice of interpreting. The ideal required the interpreter to conceal his own presence, and to become invisible, but at the same time it redefined faithfulness as accuracy to the words spoken, rather than the much more dangerous loyalty to the speaker.

\section{Conclusion}

Li Zibiao did not succeed in getting a declaration of tolerance for Chinese Christians, but then nor had the court Jesuits despite many years of trying, and all of Macartney's other requests were also refused. Nevertheless, as interpreter during the embassy he operated within the elite worlds of both the British and the most senior Qing officials. He had significant status and played a role that was important to the outcome of the negotiations. In this role he did succeed in ensuring that at the end of the embassy, when Macartney and Changlin, the newly appointed governor general of Guangdong and Guangxi, reached Guangzhou together, both the British and the senior Qing officials saw the embassy as having been a success. Changlin treated Macartney with courtesy, promised good treatment for the British merchants, and issued orders that the British were not to be molested or ill treated. ${ }^{108}$ The British did not, as the emperor had feared, use their huge warship off the coast to cause trouble. Of course Macartney's vision of the embassy as a success did not long survive the torrent of criticism he received on his return to Britain, but that was of little concern to the Qing officials or in fact to $\mathrm{Li}$, though he did continue to write to Macartney in later years. He went on to a long and successful career as a missionary in Shanxi where he founded a pious dining club for elite Catholic men and a major Catholic shrine which still survives. ${ }^{109}$

Hitherto accounts of the Macartney embassy have largely ignored $\mathrm{Li}$, but his invisibility in the record was the result at least in part of the danger of his role as an interpreter and later as a missionary. It is notable that Macartney's record of the embassy gives the names of the three other Chinese priests who accompanied the embassy to China, but not Li's, even though Macartney and nearly every other British account praises the interpreter fulsomely. ${ }^{110}$ It seems probable that this was at his own request, since he also changed his surname on leaving the embassy from Li to Mei (which also means 'plum'). ${ }^{111}$

Li Zibiao's situation, in particular the status and the power he enjoyed as an interpreter, was probably already rare in the late eighteenth century. For the British in China there were relatively few possible interpreters at this time and their knowledge arose from their unusual life stories. It was this that made it hard for either side to control the interpreter, and thus made him powerful and also put him in a position of great risk. Increasing interaction and, above all, the development of systematic published knowledge, including the publication of dictionaries and grammars as language learning tools, would soon change this. It was probably already gone for India by 1800 and would be gone for China by the time of the next British Embassy, 
Lord Amherst's in 1816. On that occasion George Thomas Staunton, who had accompanied his father on the Macartney embassy as a child and had learned Chinese from the Naples priests on the journey, was influential as an interpreter, but was clearly aligned by the British, much less successful in achieving a positive outcome, and at much less risk.

${ }^{1}$ Li Zibiao 李自標 was also known as Jacobus or Giaocomo Ly, and later in life as Jacobus Mei.

${ }^{2}$ Archivium Propaganda Fide. Rome. Scritture Originale della Congregazione Particolare Indie Orientali e Cina (hereafter APF SOCP) 68:611, Jacobus Li, 20 Februrary 1798.

${ }^{3}$ Ibid p 620.

${ }^{4}$ David Bellos, Is That a Fish in Your Ear? Translation and the Meaning of Everything (London: Penguin, 2011), 269-81.

${ }^{5}$ Kumiko Torikai, Voices of the Invisible Presence: Diplomatic Interpreters in Post-World War II Japan (Amsterdam: John Benjamins, 2009).

${ }^{6}$ Li Nanqiu 黎難秋. 中國口譯史 Zhongguo kouyi shi [A history of interpreting in China] (Qingdao 青 島: Qingdao chubanshe 青島出版社, 2002).

${ }^{7}$ See Nancy L. Hagedorn, “ 'A Friend to go between Them’: The Interpreter as Cultural Broker during Anglo-Iroquois Councils, 1740-70” Ethnohistory 35.1 (1988); Michael Cronin, Translation and Identity (London: Routledge, 2006), 82-92. For somewhat earlier periods see Natalie E. Rothman, Brokering Empire: Trans-Imperial Subjects between Venice and Istanbul (Ithaca: Columbia University Press, 2012); Sanjay Subrahmanyam, Courtly Encounters: Translating Courtliness and Violence in Early Modern Eurasia (Cambridge: Harvard University Press, 2012).

8 There are two other works on Li's interpreting: Michele Fatica, “Gli alunni del Collegium Sinicum di Napoli, la missione Macartney presso l’imperatore Qianlong e la richiesta di libertà di culto per i cristiani cinesi [1792-1793]” in S.M. Carletti, M. Sacchetti, P. Santangelo eds, Studi in onore di Lionello Lanciotti (Napoli: Istituto Universitario Orientale, 1996); Wang Hongzhi 王宏志, “Magaerni shi Hua de fanyi wenti” 馬嘎爾尼使華的翻譯問題 [The translation problems of the Macartney embassy to China] Zhongyang yanjiuyuan jindaishi yanjiusuo jikan 中央研究院近代史研究所集刊 63 (2009)).

${ }^{9}$ General Coote Public Letters, Bodleian MS. Eng. Hist. c. 68:2; General Coote Public Letters vol 2, Bodleian MS. Eng. Hist. c. 66:42-3; Minutes of Evidence taken before the Committee of the Whole House, and the Select Committee, on the Affairs of the East India Company (London, 1813), 85-6.

${ }^{10}$ Embassy to Tippoo Sultaun, British Library Add. MS. 39857-8, 1:95, 225.

${ }^{11}$ Sinnappah Arasaratnam, Merchants, Companies and Commerce on the Coromandel Coast 16501740 (Delhi: Oxford University Press, 1986), 257-8.

12 Embassy to Tippoo Sultaun, 2:170.

${ }^{13}$ Embassy to Tippoo Sultaun, 1:95, 1:229, 2:170.

${ }^{14}$ Embassy to Tippoo Sultaun, 1:86.

${ }^{15}$ Embassy to Tippoo Sultaun, 1:89, 2:170.

${ }^{16}$ Embassy to Tippoo Sultaun, 2:170.

${ }^{17}$ Embassy to Tippoo Sultaun, 2:170.

${ }^{18}$ Embassy to Tippoo Sultaun, 1:109.

${ }^{19}$ Huitong siyi guan 會同四譯館. Li Nanqiu, Zhongguo kouyi shi, 54

${ }^{20}$ Li Nanqiu, Zhongguo kouyi shi, 445; Eric Widmer, The Russian Ecclesiastical Mission in Peking during the Eighteenth Century (Cambridge: Harvard University Press, 1976), 109-10. 
${ }^{21}$ Eluosi wenguan 俄羅斯文館. Li Nanqiu, Zhongguo kouyi shi, 447; Widmer, Russian Ecclesiastical Mission, 106, 108, 160.

${ }^{22}$ Li Nanqiu, Zhongguo kouyi shi, 432-3; Kyung-ran Kim, "Foreign trade and interpreter officials" in Michael D. Shin ed. Everyday Life in Jeoson-Era Korea: Economy and Society (Leiden: Brill, 2014). ${ }^{23}$ tongshi 通事. John Robert Shepherd, Statecraft and political economy on the Taiwan frontier, 16001800 (Stanford: Stanford University Press, 1993), 13-15, 115-7.

${ }^{24}$ Hosea Ballou Morse, The Chronicles of the East India Company Trading to China, 1635-1834 (Oxford: Clarendon Press, 1926), 1:107; William C. Hunter, The 'fan kwae' at Canton before Treaty Days, 1825-1844 (London: Kegan Paul, Trench \& Co, 1882), 50-3.

${ }^{25}$ Cheng Meibao 程美寶 “Aomen zuo wei feidi de 'wei’ yu 'ji' - 16 - 19 shiji Hua yang jiaowang zhong de xiaorenwu”澳門作為飛地的 ‘危’ 與 “機” - 16-19 世紀華洋交往中的小人物[The dangers and opportunities of Macao as a foreign enclave: the common folk in Sino-Western interactions in the 16th to 19th centuries] Henan daxue хиеbao (shehui kexue ban) 52.3 (2012). ${ }^{26}$ Widmer, The Russian Ecclesiastical Mission, 13-19, 105; Si Jia 司佳, “Cong 'tongshi’ dao 'fanyiguan' - lun jindai Zhong wai yuyan jiedu shi shang de zhu/beidong jiaose de zhuanyi” 從” 通 事” 到 ‘翻譯官” - 論近代中外語言接觸史上的主, 被動角色的轉移” [From 'linguists’ to 'official translators': On the transformation between active and passive roles in the history of language contact between China and Western countries] Fudan xuebao (shehui kexue ban) 復旦學報(社會科學 版) 2002.3, 45-6.

${ }^{27}$ Catherine Jami, “Tomé Pereira (1645-1708), Clockmaker, Musician and Interpreter at the Kangxi Court: Portuguese Interests and the Transmission of Science” In Luís Saraiva and Catherine Jami eds, The Jesuits, the Padroado and East Asian Science (1552-1773) (Singapore: World Scientific, 2008). See also Peter C. Perdue, China Marches West: The Qing Conquest of Central Eurasia (Cambridge: Harvard University Press, 2005), 166-7.

${ }^{28}$ The contrary argument is made by Li Yaxi 李壓西 and Chen Weimin 陳偉民, Zhongguo jindai tongshi 中國近代通事 [Interpreters in Modern China] (Beijing 北京: Xueyuan chubanshe 學苑出版社, 2007), 30.

${ }^{29}$ George Macartney to Henry Dundas 4 January 1792, British Library India Office Records (hereafter IOR) IOR/G/12/91: 28. Punctuation altered for clarity.

${ }^{30}$ Staunton, Memoir of the Life and Family of the Late Sir George Leonard Staunton, 2, 5, 11-13, 143; Archivio Istituto Universitario Orientale Napoli (hereafter AION) 16.1.15, Giacomo Li to Francesco Massei 14 May 1792.

${ }^{31}$ Ke Zongxiao 柯宗孝 Paulus Cho; Yan Guanren 嚴寬仁 Vincentius Jen or Vincenzo Nien; Wang Ying 王英 Petrus Vam. George Leonard Staunton, An Authentic Account of an Embassy from the King of Great Britain to the Emperor of China (London: W. Bulmer, 1797. 2 vols. $4^{\circ}$ ), 41; Michele Fatica, "Gli alunni del Collegium Sinicum di Napoli." For the Chinese names see Elenchus alumnorun decreta et documenta quae spectant ad Collegium Sacrae Familiae Neapolis (Chang-hai: Typographia Missionis Catholicae, 1917).

${ }^{32} \mathrm{Li}$ Zichang 李自昌. Qing Gaozong Chun huangdi shilu 清高宗純皇帝實錄 [Veritable records of the Qing Qianlong emperor] (Beijing: Airusheng shuzihua jishu yanjiu zhongxin, n.d.), 55258; Archivio della Curia Generalizia dell’Ordine dei Fratri Minori (herafter ACGOFM), Roma, Raccolta di lettere degli alunni Cinesi dalla Cina 1753-1883, Missioni 53:74-5, 119;Qinding pingding Taiwan jilue 欽定 平定台灣紀略 [Official account of the pacification of Taiwan], (1788), juan 42 Heng Rui 1787/11/2, juan 54 Fukang'an 1788/2/11.

${ }^{33}$ Pan Yikui 潘挹奎, Wuwei qijiu zhuan 武威耆舊傳 [Biographies of Wuwei elders] (c. 1800-1830), juan 4 p 14b-15a; Li Yukai 李于鍇, Li Yukai yigao jicun 李于鍇遺稿輯存 [Collected writings left by Li Yukai] (Lanzhou 蘭州: Lanzhou daxue chubanshe 蘭州大學出版社,1987), 26-36; Li Dingwen 李 鼎文, Gansu wenshi conggao 甘肅文史叢稿 [Collected writings on Gansu literature and history] 
(Lanzhou 蘭州: Gansu renmin chubanshe 甘肅人民出版社, 1986), 273-4; Li Xiaoyan 李曉燕, Liangzhou shihua 凉州史話 [A history of Liangzhou] (蘭)州:甘肅人民出版社, 2011), 127.

${ }^{34}$ Wuwei shi minzu zongjiao zhi 武威市民族宗教志 [Wuwei city nationalities and religions gazetteer] (Lanzhou: Gansu minzu chubanshe, 2002), 229; APF SOCP 27, GB Serravalle 4 Aug 1714; APF Scritture riferite nei congressi Indie Orientali, Cina 1, Francesco d'Ottaiano, 10 Aug 1722.

${ }^{35}$ Antonius Cin et al., 13 Sept 1771, APF SOCP vol 60; Michele Fatica, Matteo Ripa e il Collegio dei Cinesi di Napoli (1682-1869): Percorso documentario e iconografico (Napoli: Università degli Studi di Napoli 'L'Orientale', 2006), 325; ACGOFM Missioni 53 Raccolta, 86.

${ }^{36}$ Michele Fatica ed. Matteo Ripa e il Collegio dei Cinesi di Napoli; Gianni Criveller, "The Chinese Priests of the College for the Chinese in Naples and the Promotion of the Indigenous Clergy (XVIIIXIX Centuries)" in Rachel Lu Yan and Philip Vanhaelemeersch eds, Silent Force: Native Converts in the Catholic China Mission (Leuven: Ferdinand Verbiest Institute, K.U.Leuven, 2009); Tiziana Ianello, "Il Collegio dei Cinei durante il decennio francese (1806-15)" in Michele Fatica and Francesco D’Arelli eds, La missione Cattolica in Cina tra i secoli XVIII-XIX: Matteo Ripa e il Collegio dei Cinesi (Napoli, 1999), 268; Michele Fatica, “ Per una mostra bibliografica ed iconografica su Matteo Ripa, il Collegio dei Cinesi e il Real Collegio Asiatico (1682-1888)” in Michele Fatica and Francesco D’Arelli eds La missione Cattolica in Cina tra i secoli XVIII-XIX: Matteo Ripa e il Collegio dei Cinesi: Atti del Colloquio Internazionale Napoli, 11-12 febbraio 1997 (Napoli, 1999), 13.

${ }^{37}$ AION 16.1.15, Jacobus Li to Ioannia Borgia, 10 Sept 1826; Di Furia, “Arte e storia nella chiesa e collegio della Sacra Famiglia ai Cinesi”, 122; Luigi Borgia, "Famiglia Borgia” Nobili Napoletani (www.nobili-napoletani.it).

${ }^{38}$ ACGOFM MH 23-2 Variae erudit.

${ }^{39}$ Felice Cappello, Progymnasmatum eloquentiae (Neapoli: Fratres Simonii, 1763).

${ }^{40}$ APF SRC Collegi Vari 10, Attn. Cardinal Sersale 24 June 1767; ACGOFM MH 10-1:13, Regole e costituzione della Congregazione e Collegio della Sacra Famiglia di Gesù Cristo.

${ }^{41}$ Nota degli Alunni Cinesi del Coll. Della S.F. di Gesu [1773], APF SRC Collegi vari 10; Gennaro Fatigati 23 Jan 1780, APF SRC Collegi vari 11; Stato di signori alunni cinesi del 1782 APF SRC Collegi vari 11.

${ }^{42}$ Nota d'Alunni Cinese 1778, APF SRC Collegi vari 10; Raccolta di lettere degli alunni Cinesi dalla Cina 1753-1883, ACGOFM Missioni 53:51.

${ }^{43}$ Nota degli alunni esistenti nel Collegio della S. Familia di Gesu Cristo 30 Nov 1776, APF SRC Collegi vari 10.

${ }^{44}$ Nota d'Alunni Cinese 1778, APF SRC Collegi vari 10.

${ }^{45}$ Francesco Massei to Cardinal Antonelli 17 March 1792, APF Collegi vai 12:131.

${ }^{46}$ Paolo Cho and Giacomo Li, 23 March 1792, AION 42.2.8.

${ }^{47}$ ACGOFM Raccolta, 145.

${ }^{48}$ Giacomo Li to Francesco Massei 14 May 1792, AION 15.1.15.

${ }^{49}$ Staunton, Memoir of the Life and Family of the Late Sir George Leonard Staunton.

${ }^{50}$ Paulus Cho cum Jacobus Li 22 May 1792, AION 16/1/16.

${ }^{51}$ Ernest Gower, A Journal of His Majesty's Ship Lion beginning the 1st October 1792 and ending the 7th September 1794 (BL Add MS 21,106), 21-31; George Thomas Staunton, Diary 1793-1794 (MS. Duke University Library), 121-3.

52 Bodleian Library, Oxford, MS Eng misc f 533-534 Lord Macartney’s Commonplace Book, 29; AION 27/10/5, Vincenzo Nien 13 April 1793; George Macartney, Journal of a Voyage from London to Cochin China 11/9/1792-15/6/1793 (Copy c. 1805. Wellcome Trust MSS 3352), 184-5.

${ }^{53}$ IOR/G/12/92: 35, Macartney to Dundas 9 Nov 1793.

${ }^{54}$ Giambattista Marchini 15 Dec 1793, AION 42/2/11.

${ }^{55}$ APF SOCP 68: 486 Marchini 3 Nov 1793. 
${ }^{56}$ Loumen 婁門.

${ }^{57}$ AION 27/10/5, Vincenzo Nien 8 July 1793; Staunton, Authentic Account of an Embassy, 1:389

${ }^{58}$ Susan Reed Stifler, “The Language Students of the East India Company's Canton Factory” Journal of the North China Branch of the Royal Asiatic Society 69 (1938); Wang Hongzhi, "Magaerni shihua de fanyi."

${ }^{59}$ IOR/G/12/93 2:210 Secret Committee 1 June 1793; IOR/G/12/93 2:227-8 Secret Committee 22 June 1793; William Alexander, Journal of Lord Macartney's Embassy to China 1792-4, 14 July 1793, British Library Add MS 35174; Yingshi Magaerni fang Hua dang'an shiliao huibian 英使馬嘎爾尼訪 華檔案史料匯編 [Collected archival materials on the English envoy Macartney's visit to China] (ed. Zhongguo di yi lishi dang'anguan 中國第一歷史檔案館; Beijing: Guoji wenhua chuban gongsi, 1996), 309-10.

${ }^{60}$ IOR/G/12/93 Macartney to EIC Secret committee 6 Aug 1793; Alexander, Journal of Lord Macartney’s Embassy to China, 22 July 1793.

${ }^{61}$ Bod MSS Eng misc b 162 Macartney papers, Miscellaneous papers, 9: APF SOCP 68:611 Jacobus Li 20 Feb 1794.

${ }^{62}$ Yingshi Magaerni fang Hua dang'an shiliao huibian, 360.

${ }^{63}$ Aeneas Anderson, A Narrative of the Embassy to China, in the years 1792, 1793, and 1794 (London:

J. Debrett, 1795), 66-7.

${ }^{64}$ John Barrow, Travels in China: Containing Descriptions, Observations, and Comparisons, Made and Collected in the course of a Short Residence at the Imperial Palace of Yuen-min-yuen, and on a subsequent journey through the country from Pekin to Canton (London: T. Cadell \& W. Davies, 1804), 88; Johann Christian Hüttner, Voyage a la Chine (Paris: J.J. Fuchs, 1798), 31; William Jardine Proudfoot, Biographical Memoir of James Dinwiddie, LL.D. Astronomer in the British Embassy to China, 1792, '3, '4: Afterwards Professor of Natural Philosophy in the College of Fort William Bengal (Liverpool: Edward Howell, 1868), 43.

${ }^{65}$ Lillian M. Li "The Garden of Perfect Brightness: The Yuanmingyuan as Imperial Paradise (17001860)" MIT Visualizing Cultures (visualizingcultures.mit.edu).

${ }^{66}$ Barrow, Travels in China, 102; George Macartney, An Embassy to China: Being the Journal kept by Lord Macartney during his Embassy to the Emperor Ch'ien-lung 1793-1794 (J.L. Cranmer-Byng ed; London: Longmans, Green \& Co, 1962), 93.

${ }^{67}$ Proudfoot, Biographical Memoir of James Dinwiddie, 44.

${ }^{68}$ Yingshi Magaerni fang Hua dang'an shiliao huibian, 1; Macartney, Embassy to China, 80.

${ }^{69}$ APF SOCP 68:609 Jacobus Li 20 Feb 1794; Macartney, Embassy to China, 80.

${ }^{70}$ IOR/G/12/92:61 Macartney to Dundas 9 Nov 1793.

${ }^{71}$ Proudfoot, Biographical Memoir, 45-6.

${ }_{72}^{7 O}$ IOR/G/12/92:61 Macartney to Dundas 9 Nov 1793.

${ }^{73}$ APF SOCP 68:612 Jacobus Li 20 Feb 1794.

${ }^{74}$ APF SOCP 68:612 Jacobus Li 20 Feb 1794.

${ }^{75}$ APF SOCP 68:612 Jacobus Li 20 Feb 1794; Anderson, Narrative of the Embassy to China, 113.

${ }^{76}$ For Macartney's opinions, which he claims to have told Zhengrui, see Macartney, Embassy to China, 93.

${ }^{77}$ APF SOCP 68:612 Jacobus Li 20 Feb 1794. See also Staunton, Authentic Account 2:136.

${ }^{78}$ Zhongtang (written 'ciuntan' in the original) is an honorific title for a Grand Secretary. APF SOCP 68:609 Jacobus Li 25 Dec 1793.

${ }^{79}$ R. Bruce W. Anderson "Perspectives on the Role of the Interpreter” in Franz Pöchhacker and Miriam Schlesinger eds. The Interpreting Studies Reader (London: Routledge, 2002), 213.

${ }^{80}$ APF SOCP 68:611 Jacobus Li 20 Feb 1794.

${ }^{81}$ Yingshi Magaerni fang Hua dang'an shiliao huibian, 51. 
${ }^{82}$ Yingshi Magaerni fang Hua dang'an shiliao huibian, 148.

${ }^{83}$ Anderson, Narrative of the Embassy to China, 186. See also p 78, 143.

${ }^{84}$ Macartney, Embassy to China, 114.

${ }^{85}$ APF SOCP 68:609-10 Jacobus Li 25 Dec 1793; Anderson, Accurate Account, 82; Hüttner, Voyage a la Chine, 85.

${ }^{86}$ APF SOCP 68:610 Jacobus Li 25 Dec 1793.

${ }^{87}$ Macartney, Embassy to China, 128.

88 Staunton, Authentic Account, 343.

${ }^{89}$ Li's encouragement: Anderson, Narrative of the Embassy, 82, 149; Macartney, Embassy to China, 148. Li’s annoyance: APF SOCP 68:609 Jacobus Li 25 Dec 1793; APF SOCP 68:613 Jacobus Li 20 Feb 1794.

90 APF SOCP 68:609 Jacobus Li 25 Dec 1793.

${ }^{91}$ APF SOCP 68:609-10 Jacobus Li 25 Dec 1793.

92 APF SOCP 68:484 Giambattista Marchini 17 Dec 1793.

${ }^{93}$ ACGOFM, Raccolta di lettere degli alunni Cinesi dalla Cina 1753-1883, Missioni 53:75, 119; Ping Tai jishi benmo 平台紀事本末 [A full account of the pacification of Taiwan] (Qing) (Taibei: Taiwan yinhang, 1958), 1787/9/14, 1787/11/12, 1788/1/11, 1788/2/11.

94 Alain Peyrefitte, The Collision of Two Civilisations: The British Expedition to China in 1792-4 (trans Jon Rothschild) (London: Harvill, 1993), 269 (Quoting George Thomas Staunton).

${ }^{95}$ APF SOCP 68:610 Jacobus Li 25 Dec 1793.

${ }^{96}$ Yingshi Magaerni fang Hua dang'an shiliao huibian, 59.

${ }^{97}$ Yingshi Magaerni fang Hua dang'an shiliao huibian, 179, 401.

${ }^{98}$ For general discussions: Macartney Embassy to China, 160-3; Yingshi Magaerni fang Hua dang'an shiliao huibian, 405-7, 415-7, 429-33.

${ }^{99}$ IOR/G/12/92:102, Macartney to Dundas 9 Nov 1793.

${ }^{100}$ Macartney, Embassy to China, 167.

${ }^{101}$ Yingshi Magaerni fang Hua dang'an shiliao huibian, 438.

102 Yingshi Magaerni fang Hua dang'an shiliao huibian, 438.

103 IOR/G/12/92:353 Note for Cho-chan-tong first Minister, 9 Nov 1793.

104 APF SOCP 68:614 Jacobus Li 20 Feb 1794.

${ }^{105}$ Yingshi Magaerni fang Hua dang'an shiliao huibian, 405, 437.

${ }^{106}$ Yingshi Magaerni fang Hua dang'an shiliao huibian, 449, 459, 469.

${ }^{107}$ Yingshi Magaerni fang Hua dang'an shiliao huibian, 478.

${ }^{108}$ Macartney, Embassy to China, 203, 209; IOR/G/12/92:471-83 The Viceroy’s $1^{\text {st }}$ edict, The Viceroy's $2^{\text {nd }}$ edict.

${ }^{109}$ APF SRC Cina e regni vol 14:275-7 Gabriele Grioglio 10 May 1851; Tianzhujiao Changzhi jiaoqu jianshi 天主教長治教區簡史[A brief history of Changzhi Catholic diocese] ('Jiaoyou shenghuo’ bianjibu〈教友生活〉編輯部, 1997.

${ }^{110}$ Macartney, Embassy to China, 64. See also Staunton, Authentic Account of an Embassy to China, 2:593; Barrow, Travels in China, 603; Anderson, Narrative of an Embassy to China, 264; Hüttner, Voyage a la Chine, 33. The only counter example is Proudfoot, Biographical Memoir of James Dinwiddie, 71, 131.

111 ACGOFM Missioni 53 Raccolta, 77 and passim. 